\title{
Usulan Perbaikan Peracangan Produk Smart Light Menggunakan Metode Design for Assembly Boothroyd- Dewhurst
}

\author{
Arief Irfan Syah Tjaja, Rochmat Puji Astomo, Rispianda \\ Jurusan Teknik Industri, Institut Teknologi Nasional (Itenas) Bandung \\ Email: ariefirfan75@gmail.com
}

\begin{abstract}
ABSTRAK
Smart Lamp product is a street lighting product which developed by PT X with LED lights concept. The design of Smart Light product is found to be slightly violate the terms of good design to the assembly process proposed by Boothroyd-Dewhurst as there is a component with sharp side, too much for using fastener, difficult fastener installation because the component is blocked and so forth. Existing design efficiency of Smart Light product is based on a calculation using the Boothroyd-Dewhurst table is $7.63 \%$ with total assembly time for 1149.1 seconds while the proposed design efficiency is $15.52 \%$ with total assembly time is 539.84 seconds. The changes of the design result reduction of the estimated product cost from Rpl.831.721, - and the BEP in 1482 products on existing product to Rp1.732.609, - and the BEP in 1283 products on proposed product.
\end{abstract}

Kata kunci: design efficiency, assembly time, estimated cost, break event point (BEP).

\begin{abstract}
Produk Smart Light adalah merupakan sebuah produk lampu penerangan jalan yang dikembangkan oleh PT X dengan konsep lampu LED. Rancangan produk Smart Light ini ternyata tidak sedikit melanggar ketentuan-ketentuan perancangan yang baik untuk proses perakitan yang dikemukakan oleh BoothroydDewhurst seperti terdapat komponen yang memiliki bagian yang tajam, penggunaan fastener yang terlalu banyak, pemasangan fastener yang sulit karena komponen terhalang dan sebagainya. Efisiensi desain existing produk Smart Light ini berdasarkan pada perhitungan menggunakan tabel Boothroyd-Dewhurst adalah 7,63\% dengan waktu perakitan total selama 1149,1 detik sedangkan efisiensi desain usulan adalah 15,52\% dengan waktu perakitan total selama 539,84 detik. Perubahan rancangan desain mengakibatkan pengurangan pada estimasi biaya produk dari Rp1.831.721,- dan break event point (BEP) pada produk ke 1482 untuk produk existing menjadi Rp1.732.609,- dan BEP pada produk ke 1283 untuk produk usulan..
\end{abstract}

Keywords: efisiensi desain, waktu perakitan, estimasi biaya, break event point 


\section{PENDAHULUAN}

\subsection{Latar Belakang}

PT X adalah perusahaan perakitan/assembly dengan lingkungan manufaktur make to order. PT X melakukan permintaan bahan baku berupa komponen pada supplier atas dasar rancangan yang telah dibuat oleh PT X. Produk-produk PT X seluruhnya dikerjakan secara manual atau dikerjakan dengan menggunakan tenaga operator. Salah satu produk yang sedang dikembangkan oleh PT X saat ini adalah produk lampu penerangan jalan berbasis lampu LED yang disebut dengan Lampu Smart Light. Saat ini, produk lampu Smart Light ini masih berupa prototype dan sedang mengalami pengembangan berupa sistem otomasi pada penggunaannya. Dengan adanya pengembangan tersebut, harga produk akan mengalami peningkatan karena ditambahkan dengan biaya pengembangan. Hal ini akan mengakibatkan berkurangnya minat konsumen terlebih sebagai produk yang ditujukan untuk kepentingan masyarakat. Harga produk Smart Light yang dapat bersaing terhadap produk kompetitor sejenis akan sangat berpengaruh terhadap keputusan calon konsumen yang dalam hal ini adalah lembaga pemerintahan yang bertanggung jawab di bidang penerangan.

Sebuah produk atau jasa memerlukan suatu pengembangan untuk dapat senantiasa memenuhi ekspektasi konsumennya. Namun, untuk mengembangkan suatu produk atau jasa sangat memungkinkan untuk diperlukannya biaya yang besar pula. Semakin besar biaya pengembangan tersebut tentunya akan berbanding lurus dengan semakin besarnya harga produk tersebut.

Harga suatu produk dipengaruhi oleh beberapa hal seperti harga material, desain, dan ongkos-ongkos yang terkait dengan proses permesinan. Design suatu produk memiliki peran yang besar dalam biaya pembuatan produk. Design suatu produk berkaitan dengan berbagai macam efisiensi berupa waktu pembuatan dan perakitan produk. Design produk yang efisien akan memiliki jumlah komponen yang sedikit dan bentuk yang sederhana tanpa harus menghambat atau mengurangi fungsi kerjanya. Penelitian ini bertujuan untuk melakukan perbaikan desain untuk meminimasi waktu perakitan produk pada rancangan produk smart light menggunakan metode design for assembly boothroyd-dewhurst. Penelitian ini juga menganalisis apakah desain usulan dapat dan layak untuk dilakukan proses produksinya dengan mengestimasikan biaya pembuatan produk dan Break Event Point.

\subsection{Design for Assembly (DFA)}

DFA adalah design komponen dengan mempertimbangkan bagaimana suatu produk akan dirakit untuk memastikan bahwa biaya perakitan diminimalkan (Boothroyd-Dewhurst, 1994). DFA juga merupakan rangkaian proses untuk meningkatkan design produk sehingga kemudahan dan perakitan yang lebih murah dicapai perusahaan, memfokuskan kepada aspek fungsional dan kemudahrakitan secara bersamaan.

Berikut ini adalah prinsip dasar dalam melakukan DFA menurut Corbettt, Dooner, Meleba dan Pym (1991).

1) Design produk harus meminimalkan komponen dan fixings, variasi desain, gerakan perakitan dan arah perakitan.

2) Desain produk harus memiliki chamfer yang sesuai, penjajaran alami (natural alignment), akses mudah untuk memosisikan permukaan, komponen yang simetris atau asimetris yang dibesarkan dan handling dan transportasi yang mudah.

3) Desain produk harus terdiri dari komponen-komponen yang menghalangi pandangan (visual obstruction), operasi fitting yang bersamaan, komponen yang menyangkut (tangling) atau tersembunyi (nesting).

4) Setelan yang berefek pada penyetelan sebelumnya.

5) Kemungkinan kesalahan perakitan lainnya. 
Untuk menjelaskan lebih lanjut prinsip dalam DFA, berikut ini adalah beberapa peraturan tambahannya.

1) Mengurangi jumlah komponen bila memungkinkan.

2) Membangun komponen dalam lapisan dari atas permukaan ke bagian bawah dengan memanfaatkan gravitasi untuk meletakkan komponen yang dirakit.

3) Produk yang sudah dirakit terlebih dahulu berada dalam kondisi stabil pada permukaan meja kerja yang horizontal dan harus terlihat (accessible \& visible).

4) Gunakan chamfers dan fillet untuk memudahkan pencocokan bagian.

5) Gunakan snap-fit dan pengencang cepat lainnya, hindari skrup, lem, dll.

\subsection{Design for Assembly Boothroyd-dewhurst}

Proses perakitan manual dapat dibagi secara alami menjadi dua wilayah yang terpisah, penanganan (memperoleh, orientasi dan memindahkan bagian-bagian) dan penyisipan dan pengikatan (pemasangan bagian ke bagian lain atau sub bagian).

Sistem klasifikasi untuk proses perakitan adalah pengaturan sistematis dari struktur komponen yang mempengaruhi akuisisi, gerakan, orientasi, penyisipan, dan pengikatan komponen.

Pedoman Desain untuk Penanganan Komponen (Handling):

1) Desain komponen yang memiliki end-to-end simetri dan simetri rotasi dengan sumbu penyisipan. Jika ini tidak dapat dicapai, coba untuk merancang komponen yang memiliki kemungkinan simetri maksimum.

2) Bagian dalam desain yang dimana dalam komponen itu tidak dapat dibuat simetris, perjelas asimetrisnya.

3) Menyediakan fitur yang akan mencegah kemacetan dari komponen yang cenderung menyarang atau menumpuk bila disimpan dalam jumlah besar.

4) Hindari fitur yang akan memungkinkan kekusutan bagian bila disimpan dalam jumlah besar.

5) Hindari komponen yang tetap menyatu atau licin, halus, fleksibel, sangat kecil, atau sangat besar atau yang berbahaya bagi operator (bagian yang tajam, mudah pecah, dll).

Pedoman Desain untuk Penyisipan dan Pengikatan (Insertion):

1) Merancang sehingga ada sedikit atau tidak ada resistensi terhadap penyisipan dan memberikan chamfers untuk memandu penyisipan antar dua komponen yang dipasang.

2) Standarisasi dengan menggunakan komponen, proses, dan metode yang umum pada semua model.

3) Menggunakan piramida perakitan untuk perakitan progresif sekitar satu sumbu referensi.

4) Hindari kebutuhan untuk memegang bagian bawah untuk menjaga orientasi selama manipulasi subassembly atau selama penempatan bagian lain

5) Komponen harus terletakkan sebelum dilepaskan.

6) Menggunakan pengencang mekanik umum dengan biaya relatif proses pengikatan yang kecil.

7) Menghindari kebutuhan untuk memposisikan perakitan sebagian selesai di fixture.

\subsection{Manajemen Keuangan}

Fungsi manajemen keuangan terdiri dari tiga keputusan utama yang harus dilakukan oleh suatu perusahaan; keputusan investasi, keputusan pendanaan, dan keputusan dividen. Masing-masing keputusan harus berorientasi pada pencapaian tujuan perusahaan. Kombinasi dari ketiganya akan memaksimumkan nilai perusahaan.

Tujuan utama didirikannya suatu perusahaan adalah mencari keuntungan yang optimal. Analisis terhadap saling berhubungan antara unsur-unsur yang membentuk laba juga sering disebut sebagai 
analisis break event point. Dasar yang digunakan dalam analisis break event point ini adalah perilaku biaya dalam kaitannya dengan hasil penjualan.

Ada dua cara dalam menentukan break event point yaitu pendekatan grafik dan pendekatan matematik. Dalam perhitungan BEP dengan pendekatan matematik dapat dilakukan dengan dua cara, yaitu atas dasar unit dan atas dasar rupiah.

Rumus BEP dalam unit dapat diformulasikan sebagai berikut:

$B E P_{\text {unit }}=\frac{B T}{P-V}$

Sedangkan rumus BEP dalam rupiah dapat diformulasikan sebagai berikut:

$B E P_{R p}=\frac{B T}{1-\frac{V}{P}}$

Dengan:

$\mathrm{P}=$ Harga jual per unit

$\mathrm{V}=$ Biaya variabel per unit

$\mathrm{BT}=$ Biaya tetap total selama setahun

\section{METODOLOGI}

Desain produk yang efisien akan memiliki jumlah komponen yang sedikit dan bentuk yang sederhana tanpa harus menghambat atau mengurangi fungsi kerjanya. Hal tersebut akan sangat berpengaruh besar pada waktu pengerjaan produk, khususnya dalam hal perakitan produk. Salah satu metode yang dapat digunakan untuk melakukan perancangan ulang produk adalah metode Design for Assembly (DFA) yang dikembangkan oleh Boothroyd-Dewhurst. Kelebihan dari metode ini adalah dapat mengestimasikan pengurangan waktu perakitan antara desain existing dengan desain usulannya, serta dapat dilakukan pula perhitungan mengenai peningkatan efisiensi desainnya. Untuk merancang ulang produk, hal yang diperlukan adalah berupa data-data karakteristik tentang produk yang sudah ada (existing) yang nantinya akan dianalisis dan diperbandingkan dengan analisis karakteristik produk usulannya. Analisis yang diperlukan sebagai output dari penelitian adalah berupa waktu total perakitan produk, jumlah dari komponen, efisiensi desain, serta pertimbangan tentang estimasi harga serta titik balik modal juga perlu untuk dipertimbangkan untuk mengetahui apakah desain usulan benar-benar dapat meminimasi harga dari produk yang sudah ada.

Metodologi penelitian merupakan langkah-langkah yang akan dilakukan dalam penelitian untuk mencapai tujuan yang diinginkan. Langkah-langkah pemecahan masalah dalam pengembangan algoritma ini dapat dilihat pada Gambar 1. 


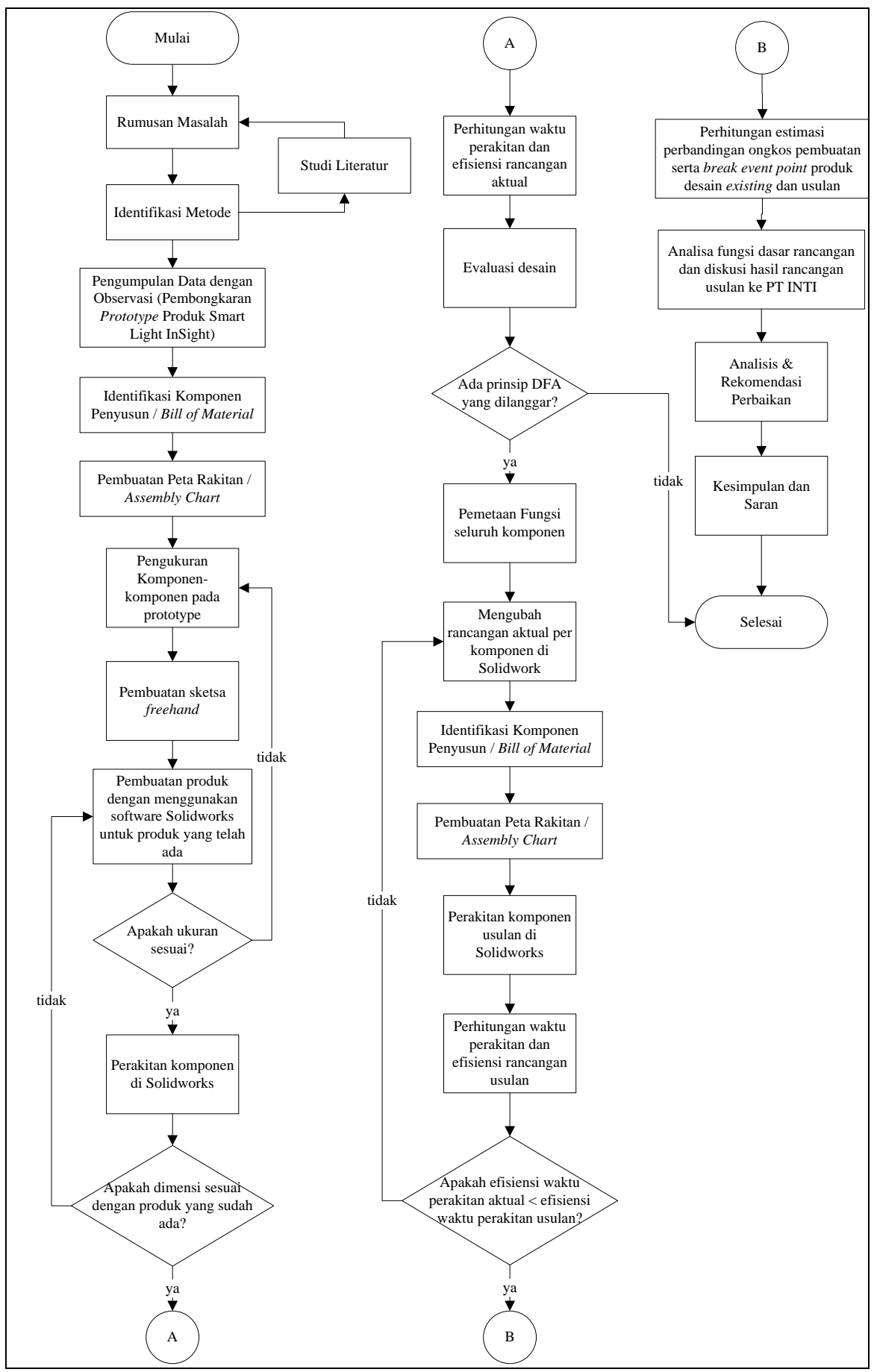

Gambar 1. Langkah-langkah Pemecahan Masalah

Dalam penelitian ini secara garis besar terdapat 2 tahap, yaitu:

\subsection{Pengumpulan Data dan Analisis Desain Produk yang Sudah Ada}

Pengumpulan data dan analisis desain produk yang sudah ada dilakukan melalui beberapa langkah yaitu:

1) Pembongkaran prototype produk Smart Light.

2) Penyusunan Bill of Material Produk Existing (yang sudah ada).

3) Pembuatan Assembly Chart Produk Existing.

4) Perhitungan efisiensi desain Boothroyd-Dewhurst produk existing. 
5) Perhitungan estimasi ongkos pembuatan produk dan break event point produk existing.

\subsection{Perancangan Desain Produk Usulan}

Perancangan desain produk usulan dilakukan melalui beberapa langkah yaitu:

1) Analisis kekurangan dan ruang perbaikan produk existing berdasarkan prinsip DFA.

2) Perancangan solusi desain berdasarkan analisis terhadap rancangan existing.

3) Penyusunan Bill of Material produk usulan.

4) Pembuatan Assembly Chart produk usulan.

5) Perhitungan efisiensi desain Boothroyd-Dewhurst produk usulan.

6) Perhitungan estimasi ongkos pembuatan produk dan break event point produk usulan.

\section{HASIL DAN PEMBAHASAN}

\subsection{Pengumpulan Data dan Analisis Desain Produk yang Sudah Ada (Existing)}

1) Pembongkaran prototype produk Smart Light.

Untuk dapat melakukan proses DFA, terlebih dahulu penulis mengidentifikasi komponen-komponen Smart Light dengan melakukan disassembly terhadap prototype Smart Light. Berikut ini adalah exploded view dari rancangan existing Smart Light:

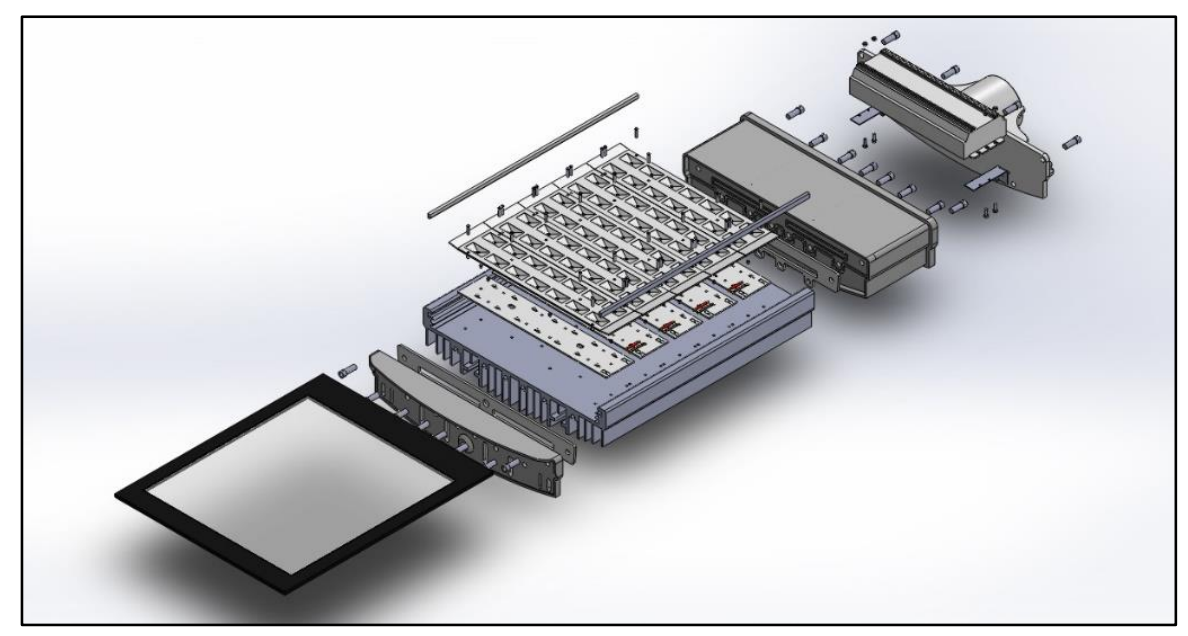

Gambar 2. Exploded View Desain Existing Smart Light

2) Penyusunan Bill of Material Produk Existing (yang sudah ada).

Untuk dapat mengetahui struktur produk dari Smart Light, berikut ini adalah Bill of Material dari Smart Light. 
Arief Irfan Syah Tjaja, Rochmat Puji Astomo, Rispianda

Tabel 1. Bill of Material Produk Existing

\begin{tabular}{|c|c|c|c|c|c|c|}
\hline \multicolumn{7}{|c|}{ Bill of Materials } \\
\hline No & Part Number & Level & Description & $\begin{array}{c}\text { Quantity of } \\
\text { Each Assembly }\end{array}$ & Unit of Measurement & Decision \\
\hline 1 & NL 200 / IP 65 & 0 & Lampu & 1 & SET & $M A K E$ \\
\hline 2 & A100 & 1 & Bagian Atas & 1 & SET & $M A K E$ \\
\hline 3 & 1100 & 2 & Karet Penghubung Penutup Atas & 1 & $E A C H$ & $B U Y$ \\
\hline 4 & 1200 & 2 & Penutup Atas & 1 & $E A C H$ & $B U Y$ \\
\hline 5 & 1300 & 2 & Fastener 1 & 8 & $E A C H$ & $B U Y$ \\
\hline 6 & B200 & 1 & Bagian Lampu & 1 & SET & $M A K E$ \\
\hline 7 & 1400 & 2 & Badan Atas & 1 & $E A C H$ & $B U Y$ \\
\hline 8 & 1500 & 2 & PCB LED & 5 & $E A C H$ & $B U Y$ \\
\hline 9 & 1600 & 2 & Fastener 2 & 20 & $E A C H$ & $B U Y$ \\
\hline 10 & 1700 & 2 & Kabel Penghubung PCB & 4 & $E A C H$ & $B U Y$ \\
\hline 11 & 1800 & 2 & Papan Pembias & 5 & $E A C H$ & $B U Y$ \\
\hline 12 & 1900 & 2 & Fastener 3 & 30 & $E A C H$ & $B U Y$ \\
\hline 13 & 2000 & 2 & Karet Kaca & 2 & $E A C H$ & $B U Y$ \\
\hline 14 & 2100 & 2 & Kaca & 1 & $E A C H$ & $B U Y$ \\
\hline 15 & $\mathrm{C} 300$ & 1 & Bagian Badan Bawah & 1 & SET & $M A K E$ \\
\hline 16 & 2200 & 2 & Karet Penghubung Badan Bawah & 1 & $E A C H$ & $B U Y$ \\
\hline 17 & 2300 & 2 & Badan Bawah & 1 & $E A C H$ & $B U Y$ \\
\hline 18 & 2400 & 2 & Fastener 1 & 8 & $E A C H$ & $B U Y$ \\
\hline 19 & D400 & 1 & Bagian Bawah & 1 & SET & $M A K E$ \\
\hline 20 & 2500 & 2 & Penutup Bawah & 1 & $E A C H$ & $B U Y$ \\
\hline 21 & 2600 & 2 & Dudukan LED Driver & 2 & $E A C H$ & $B U Y$ \\
\hline 22 & 2700 & 2 & LED Driver & 1 & $E A C H$ & $B U Y$ \\
\hline 23 & 2800 & 2 & Mur & 6 & $E A C H$ & $B U Y$ \\
\hline 24 & 2900 & 2 & Baut & 6 & $E A C H$ & $B U Y$ \\
\hline 25 & 3000 & 2 & Kabel LED Driver & 1 & $E A C H$ & $B U Y$ \\
\hline 26 & 3100 & 2 & Fastener 1 & 6 & $E A C H$ & $B U Y$ \\
\hline
\end{tabular}

3) Pembuatan Assembly Chart Produk Existing.

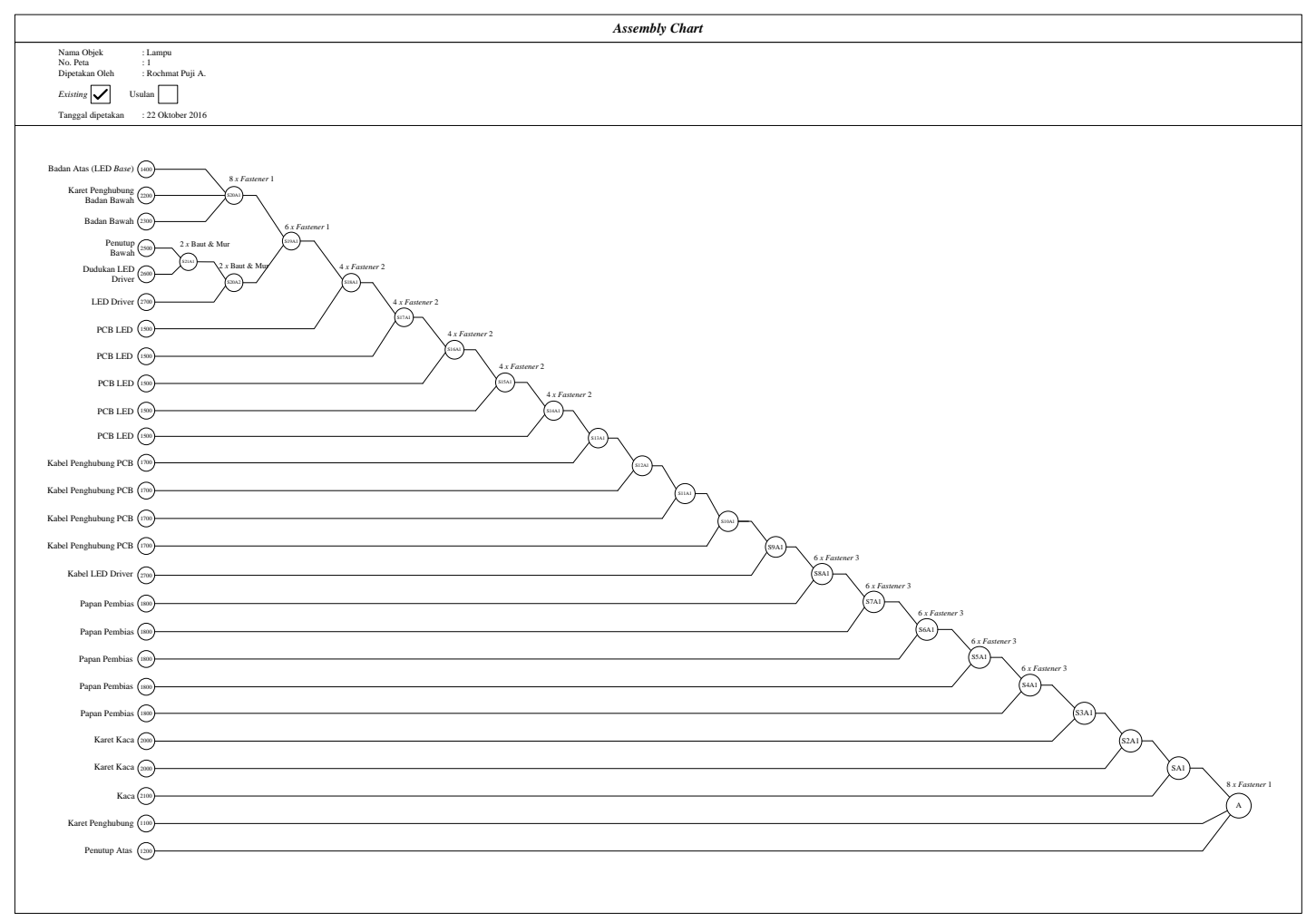

Gambar 3. Assembly Chart Desain Usulan

Jurnal Rekayasa Hijau - 214 
Usulan Perbaikan Peracangan Produk Smart Light Menggunakan Metode Design for Assembly BoothroydDewhurst

4) Perhitungan efisiensi desain Boothroyd-Dewhurst produk existing..

Proses selanjutnya dalam metode DFA adalah melakukan perhitungan untuk mengetahui waktu perakitan secara teoritis dan juga efisiensi desain dari rancangan existing Smart Light dengan menggunakan tabel Boothroyd-Dewhurst.

Tabel 2. Perhitungan Boothroyd-Dewhurst Desain Produk Existing

\begin{tabular}{|c|c|c|c|c|c|c|c|c|c|c|c|c|}
\hline No & Komponen & Jumlah & Alpha & Beta & $\begin{array}{c}\text { Tool } \\
\text { Acquire } \\
\text { Time } \\
\text { (TA) }\end{array}$ & $\begin{array}{l}2 \text { Digit } \\
\text { Handling } \\
\text { Code }\end{array}$ & $\begin{array}{l}\text { Handling } \\
\text { Time (sec) }\end{array}$ & $\begin{array}{c}2 \text { Digit } \\
\text { Insertion } \\
\text { Code }\end{array}$ & $\begin{array}{l}\text { Insertion } \\
\text { Time (sec) }\end{array}$ & $\begin{array}{c}\text { Total } \\
\text { Handling }\end{array}$ & $\begin{array}{c}\text { Total } \\
\text { Insertion }\end{array}$ & $\begin{array}{l}\text { Jumlah } \\
\text { Teoritis }\end{array}$ \\
\hline 1 & Badan Atas (LED Base) & 1 & 360 & 360 & & $9-5$ & 4 & $0-1$ & 2,5 & 4 & 2,5 & 1 \\
\hline 2 & Karet Penghubung Badan Bawah & 1 & 180 & 360 & & $2-5$ & 2,57 & $0-2$ & 2,5 & 2,57 & 2,5 & \\
\hline 3 & Badan Bawah & 1 & 360 & 360 & & $3-0$ & 1,95 & $1-3$ & 6 & 1,95 & 6 & 1 \\
\hline 4 & Fastener 1 & 8 & 360 & 0 & 2,9 & $1-1$ & 1,8 & $4-9$ & 10,5 & 14,4 & 84 & \\
\hline 5 & Penutup Bawah & 1 & 360 & 360 & & $3-0$ & 1,95 & $0-1$ & 2,5 & 1,95 & 2,5 & 1 \\
\hline 6 & Dudukan LED Driver & 2 & 360 & 360 & & $3-0$ & 1,95 & $0-7$ & 6,5 & 3,9 & 13 & \\
\hline 7 & LED Driver & 1 & 360 & 180 & & $2-0$ & 1,8 & $1-9$ & 10 & 1,8 & 10 & 1 \\
\hline 8 & Mur & 6 & 180 & 0 & & $0-4$ & 2,18 & $4-8$ & 8,5 & 13,08 & 51 & \\
\hline 9 & Baut & 6 & 360 & 0 & 2,9 & $1-1$ & 1,8 & $4-8$ & 8,5 & 10,8 & 51 & \\
\hline 10 & Fastener 1 & 6 & 360 & 0 & 2,9 & $1-1$ & 1,8 & $3-9$ & 8 & 10,8 & 48 & \\
\hline 11 & Reorientasi & 1 & 360 & 360 & & $9-5$ & 4 & $0-1$ & 2,5 & 4 & 2,5 & \\
\hline 12 & PCB LED & 5 & 360 & 360 & & $3-0$ & 1,95 & $0-3$ & 3,5 & 9,75 & 17,5 & 1 \\
\hline 13 & Fastener 2 & 20 & 360 & 0 & 2,9 & $1-1$ & 1,8 & $3-9$ & 8 & 36 & 160 & \\
\hline 14 & Kabel Penghubung PCB & 8 & 180 & 180 & 2,9 & $1-3$ & 2,06 & $9-5$ & 8 & 16,48 & 64 & \\
\hline 15 & Kabel LED Driver & 2 & 360 & 360 & 2,9 & $3-1$ & 2,25 & $9-5$ & 8 & 4,5 & 16 & 2 \\
\hline 16 & Papan Pembias & 5 & 360 & 180 & & $2-0$ & 1,8 & $0-3$ & 3,5 & 9 & 17,5 & 1 \\
\hline 17 & Fastener 3 & 30 & 360 & 0 & 2,9 & $1-2$ & 2,25 & $3-9$ & 8 & 67,5 & 240 & \\
\hline 18 & Karet Kaca & 2 & 180 & 180 & & $1-5$ & 2,25 & $4-3$ & 7,5 & 4,5 & 15 & \\
\hline 19 & Reorientasi & 1 & 360 & 360 & & $9-5$ & 4 & $0-1$ & 2,5 & 4 & 2,5 & \\
\hline 20 & Kaca & 1 & 360 & 360 & & $9-3$ & 3 & $4-4$ & 8,5 & 3 & 8,5 & 1 \\
\hline 21 & Karet Penghubung Penutup Atas & 1 & 180 & 360 & & $2-5$ & 2,57 & $0-2$ & 2,5 & 2,57 & 2,5 & \\
\hline 22 & Penutup Atas & 1 & 360 & 360 & & $3-0$ & 1,95 & $0-3$ & 3,5 & 1,95 & 3,5 & \\
\hline 23 & Fastener 1 & 8 & 360 & 0 & 2,9 & $1-1$ & 1,8 & $3-9$ & 8 & 14,4 & 64 & \\
\hline \multicolumn{2}{|c|}{ Jumlah } & 118 & & & 23,2 & & & & & 242,9 & 884 & 9 \\
\hline \multirow{2}{*}{\multicolumn{2}{|c|}{ Total Waktu Assembly }} & 1150,1 & & & & & & & & & & \\
\hline & & $7,63 \%$ & & & & & & & & & & \\
\hline
\end{tabular}

Selain melakukan perhitungan waktu perakitan dan efisiensi desain, diperlukan pula perhitungan ongkos pembuatan produk untuk mengetahui estimasi total biaya yang dibutuhkan untuk membuat satu produk. Perhitungan estimasi total biaya pembuatan produk existing dapat dilihat pada Tabel 3.

Tabel 3. Estimasi Total Biaya Pembuatan Produk Existing dan BEP

\begin{tabular}{|c|c|c|c|c|c|}
\hline \multirow{2}{*}{ Biaya Material } & Material Komponen & $\mathrm{Rp}$ & 1.044 .715 & & \multirow[b]{3}{*}{1.131 .515} \\
\hline & Material Fastener & $\mathrm{Rp}$ & 86.800 & & \\
\hline & & & & $\mathrm{Rp}$ & \\
\hline \multirow{2}{*}{ Biaya Fabrikasi } & Permesinan & $\mathrm{Rp}$ & 606.229 & & \\
\hline & Operator & $\mathrm{Rp}$ & 50.492 & & \\
\hline & & & & $\mathrm{Rp}$ & 656.721 \\
\hline \multirow{2}{*}{ Biaya Depresiasi } & Mesin & $\mathrm{Rp}$ & 30.456 & & \\
\hline & Cetakan & $\mathrm{Rp}$ & 13.030 & & \\
\hline & & & & $\mathrm{Rp}$ & $43.485,06$ \\
\hline \multicolumn{4}{|c|}{ Estimasi Total Biaya Pembuatan Produk Existing } & Rp & 1.831 .721 \\
\hline \multicolumn{2}{|l|}{ Kapasitas } & & 50000 & & \\
\hline \multicolumn{4}{|l|}{ Profit } & $\mathrm{Rp}$ & 33.413 .971 .962 \\
\hline \multicolumn{2}{|l|}{ Harga Produk } & $\mathrm{Rp}$ & $2.500 .000,00$ & & \\
\hline \multicolumn{2}{|l|}{ Investasi } & $\mathrm{Rp}$ & $989.750 .000,00$ & & \\
\hline \multicolumn{4}{|l|}{ Break Event Point } & & 1482 \\
\hline
\end{tabular}

\subsection{Perancangan Desain Produk Usulan}

1) Analisis kekurangan dan ruang perbaikan produk existing berdasarkan prinsip DFA.

Identifikasi kekurangan dan ruang perbaikan produk existing dapat dilihat pada Tabel 4 . 
Tabel 4. Analisis Kekurangan dan Ruang Perbaikan Produk Existing Berdasarkan Prinsip DFA

\begin{tabular}{|c|c|c|c|}
\hline No & Komponen & Kekurangan Rancangan & Perbaikan \\
\hline \multirow[t]{2}{*}{1} & \multirow{2}{*}{$\begin{array}{c}\text { Badan Atas (LED } \\
\text { Base) }\end{array}$} & $\begin{array}{c}\text { Fitur pendingin berbentuk sirip pada komponen } \\
\text { ini memiliki kontur yang tajam di bagian ujung } \\
\text { sehingga membahayakan bagi operator }\end{array}$ & Pada ujung-ujung sirip diberi chamfer \\
\hline & & $\begin{array}{l}\text { Tidak terdapat fitur self-locating untuk } \\
\text { peletakkan papan PCB LED pada LED Base }\end{array}$ & $\begin{array}{l}\text { Pada komponen LED Base diberi self- } \\
\text { locating }\end{array}$ \\
\hline 2 & Kaca & $\begin{array}{l}\text { Masing-masing ujung sudut pada komponen ini } \\
\text { memiliki kontur yang tajam sehingga dapat } \\
\text { menyebabkan kesulitan dalam proses insersinya }\end{array}$ & Pada ujung-ujung kaca diberi chamfer \\
\hline \multirow{2}{*}{3} & \multirow{2}{*}{ Papan PCB LED } & $\begin{array}{c}\text { Jumlah papan PCB LED yang digunakan bisa } \\
\text { diminimisasi }\end{array}$ & $\begin{array}{l}\text { Penggabungan penggunaan lima papan PCB } \\
\text { LED menjadi satu komponen }\end{array}$ \\
\hline & & $\begin{array}{c}\text { Banyak lubang untuk fastener pada komponen } \\
\text { ini yang tidak digunakan }\end{array}$ & $\begin{array}{c}\text { Redesign tata letak lubang fastener pada } \\
\text { PCB LED }\end{array}$ \\
\hline 4 & \begin{tabular}{|c|} 
Kabel Penghubung \\
PCB
\end{tabular} & $\begin{array}{c}\text { Jumlah Kabel Penghubung PCB yang digunakan } \\
\text { bisa dihilangkan }\end{array}$ & $\begin{array}{c}\text { Dihilangkan (Papan-papan PCB LED } \\
\text { digabungkan) }\end{array}$ \\
\hline 5 & Papan Pembias & $\begin{array}{c}\text { Jumlah Papan Pembias yang digunakan bisa } \\
\text { diminimisasi }\end{array}$ & $\begin{array}{l}\text { Penggabungan penggunaan lima papan } \\
\text { pembias menjadi satu komponen }\end{array}$ \\
\hline \multirow[b]{2}{*}{6} & \multirow[b]{2}{*}{ Badan Bawah } & $\begin{array}{c}\text { Terlalu banyak ruang kosong yang tidak } \\
\text { digunakan }\end{array}$ & $\begin{array}{c}\text { Didesain ulang dengan menghilangkan ruang } \\
\text { kosong }\end{array}$ \\
\hline & & $\begin{array}{c}\text { Lubang untuk fastener terlalu menjorok } \\
\text { kedalam sehingga menyulitkan dalam proses } \\
\text { fastening }\end{array}$ & Didesain ulang agar lebih mudah untuk dirakit \\
\hline \multirow{2}{*}{7} & \multirow{2}{*}{ LED Driver } & $\begin{array}{c}\text { Tidak mampu mengakomodasi perakitan } \\
\text { langsung ke Penutup Bawah }\end{array}$ & $\begin{array}{c}\text { Perancangan ulang komponen Penutup Bawah } \\
\text { atau dirakit dengan komponen lain }\end{array}$ \\
\hline & & $\begin{array}{l}\text { Rancangan mengakibatkan variansi penggunaan } \\
\text { fastener (harus menggunakan baut dan mur) }\end{array}$ & $\begin{array}{l}\text { Dirancang ulang pada bagian penampangnya } \\
\text { agar dapat dirakit dengan menggunakan screw }\end{array}$ \\
\hline 8 & $\begin{array}{l}\text { Dudukan LED } \\
\text { Driver }\end{array}$ & $\begin{array}{c}\text { Secara teoritis tidak dibutuhkan karena hanya } \\
\text { menjadi penghubung untuk LED driver dan } \\
\text { Penutup Bawah }\end{array}$ & Dihilangkan \\
\hline 9 & Karet penghubung & $\begin{array}{c}\text { Bentuk yang fleksibel dapat mempersulit } \\
\text { perakitan }\end{array}$ & $\begin{array}{c}\text { Perancangan kembali komponen Penutup Atas } \\
\text { dan Badan Bawah agar dapat mengakomodasi } \\
\text { fleksibilitas karet penghubung }\end{array}$ \\
\hline 10 & Penutup bawah & Tidak ada prinsip dasar DFA yang terlanggar & $\begin{array}{l}\text { Meskipun tidak ada prinsip dasar DFA yang } \\
\text { terlanggar namun komponen yang akan dirakit } \\
\text { mengalami perubahan desain, untuk itu } \\
\text { komponen ini perlu didesain ulang juga. }\end{array}$ \\
\hline 11 & Fastener & $\begin{array}{c}\text { Jumlah fastener yang digunakan bisa } \\
\text { diminimasi }\end{array}$ & $\begin{array}{c}\text { Perancangan kembali komponen-komponen } \\
\text { yang menggunakan fastener }\end{array}$ \\
\hline
\end{tabular}

2) Perancangan solusi desain berdasarkan analisis terhadap rancangan existing.

Berikut ini adalah exploded view dari rancangan usulan Smart Light: 


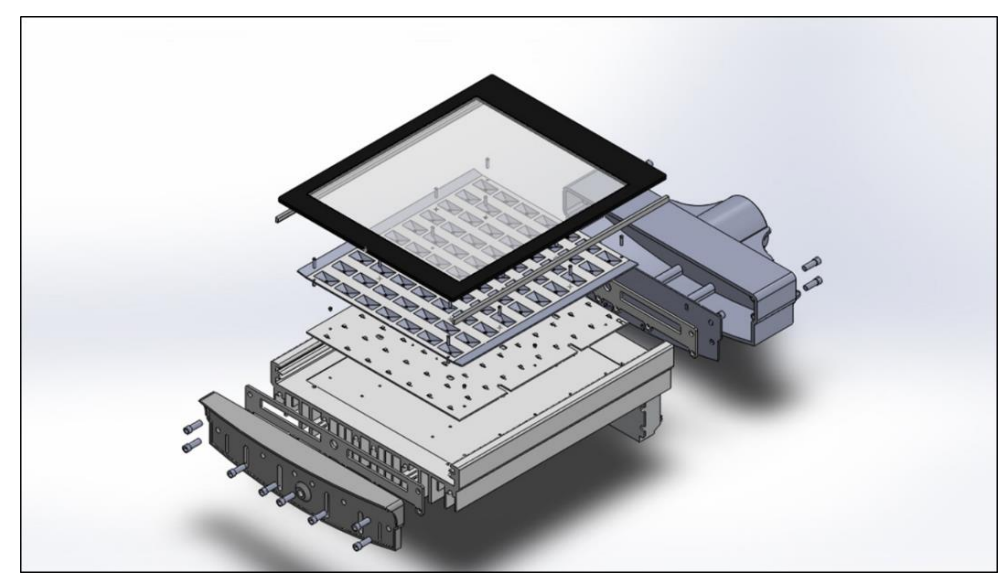

Gambar 4. Exploded View Desain Existing Smart Light

3) Penyusunan Bill of Material produk usulan.

Untuk dapat mengetahui struktur usulan dari produk Smart Light, berikut ini adalah Bill of Material dari usulan produk Smart Light yang dapat dilihat pada Tabel 5.

Tabel 5. Bill of Material Produk Usulan

\begin{tabular}{|c|c|c|c|c|c|c|}
\hline \multicolumn{7}{|c|}{ Bill of Materials } \\
\hline No & Part Number & Level & Description & $\begin{array}{c}\text { Quantity of } \\
\text { Each Assembly }\end{array}$ & Unit of Measurement & Decision \\
\hline 1 & NL $200 /$ IP 65 & 0 & Lampu & 1 & SET & $M A K E$ \\
\hline 2 & A 100 & 1 & Bagian A tas & 1 & SET & $M A K E$ \\
\hline 3 & 1100 & 2 & Karet Penghubung Penutup A tas & 1 & $E A C H$ & $B U Y$ \\
\hline 4 & 1200 & 2 & Penutup Atas & 1 & $E A C H$ & $B U Y$ \\
\hline 5 & 1300 & 2 & Fastener 1 & 6 & $\mathrm{EACH}$ & $B U Y$ \\
\hline 6 & B200 & 1 & Bagian Lampu & 1 & SET & $M A K E$ \\
\hline 7 & 1400 & 2 & Badan Atas (LED Base) & 1 & $\mathrm{EACH}$ & $B U Y$ \\
\hline 8 & 1500 & 2 & PCB LED & 1 & $E A C H$ & $B U Y$ \\
\hline 9 & 1600 & 2 & Fastener 2 & 12 & $E A C H$ & $B U Y$ \\
\hline 10 & 1700 & 2 & Papan Pembias & 1 & $E A C H$ & $B U Y$ \\
\hline 11 & 1800 & 2 & Fastener 3 & 14 & $E A C H$ & $B U Y$ \\
\hline 12 & 1900 & 2 & Karet Kaca & 2 & $E A C H$ & $B U Y$ \\
\hline 13 & 2000 & 2 & Kaca & 1 & $\mathrm{EACH}$ & $B U Y$ \\
\hline 14 & $\mathrm{C} 300$ & 1 & Bagian Bawah & 1 & $S E T$ & $M A K E$ \\
\hline 15 & 2100 & 2 & Karet Penghubung Badan Bawah & 1 & $\mathrm{EACH}$ & $B U Y$ \\
\hline 16 & 2200 & 2 & Badan Bawah & 1 & $E A C H$ & $B U Y$ \\
\hline 17 & 2300 & 2 & Dudukan LED Driver & 2 & $E A C H$ & $B U Y$ \\
\hline 18 & 2400 & 2 & LED Driver & 1 & $E A C H$ & $B U Y$ \\
\hline 19 & 2500 & 2 & Kabel LED Driver & 2 & $E A C H$ & $B U Y$ \\
\hline 20 & 2600 & 2 & Fastener 1 & 2 & $\mathrm{EACH}$ & $B U Y$ \\
\hline 21 & 2700 & 2 & Penutup Bawah & 1 & $E A C H$ & $B U Y$ \\
\hline 22 & 2800 & 2 & Fastener 1 & 8 & $\mathrm{EACH}$ & $B U Y$ \\
\hline
\end{tabular}

4) Pembuatan Assembly Chart produk usulan.

Proses perakitan per komponen pada rancangan produk usulan Smart Light dapat dilihat pada assembly chart Smart Light berikut. 


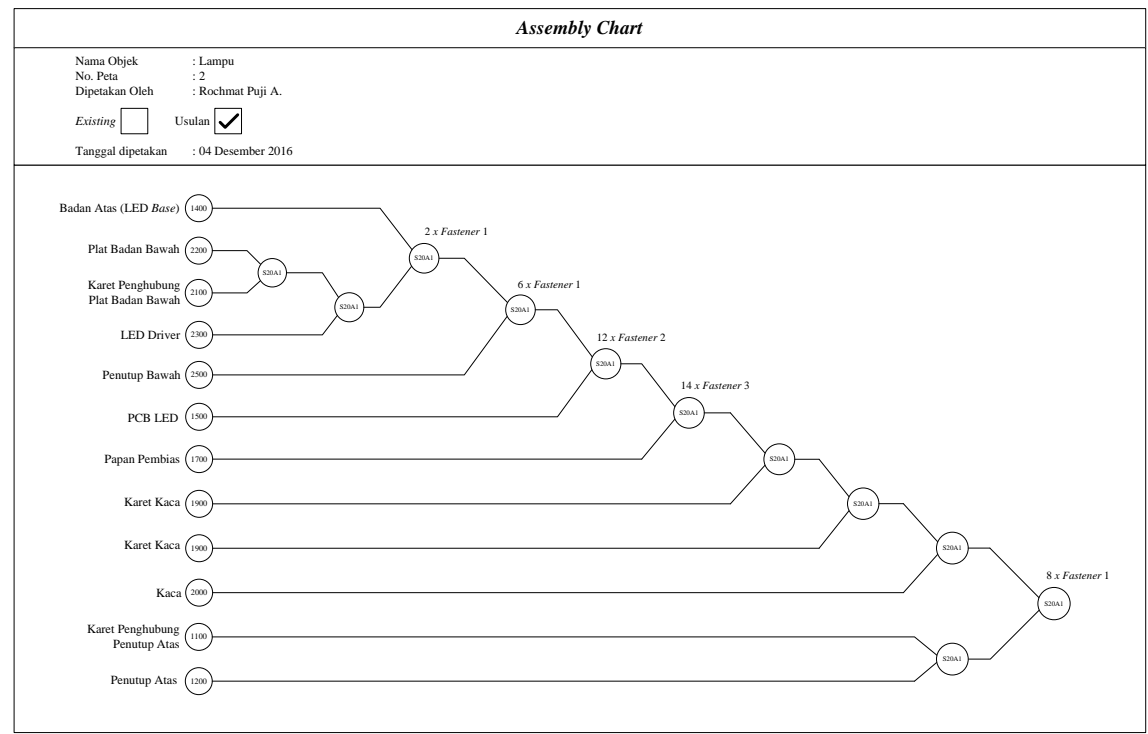

Gambar 5. Assembly Chart Desain Usulan

5) Perhitungan efisiensi desain Boothroyd-Dewhurst produk usulan.

Proses selanjutnya adalah melakukan perhitungan untuk mengetahui waktu perakitan secara teoritis dan juga efisiensi desain dari rancangan usulan Smart Light dengan menggunakan tabel BoothroydDewhurst.

Tabel 6. Perhitungan Boothroyd-Dewhurst Desain Produk Usulan

\begin{tabular}{|c|c|c|c|c|c|c|c|c|c|c|c|c|}
\hline No & Komponen & Jumlah & Alpha & Beta & $\begin{array}{c}\text { Tool } \\
\text { Acquire } \\
\text { Time } \\
\text { (TA) }\end{array}$ & $\begin{array}{c}2 \text { Digit } \\
\text { Handling } \\
\text { Code }\end{array}$ & Handling & $\begin{array}{c}2 \text { Digit } \\
\text { Insertion } \\
\text { Code }\end{array}$ & Insertion & $\begin{array}{c}\text { Total } \\
\text { Handling }\end{array}$ & $\begin{array}{c}\text { Total } \\
\text { Insertion }\end{array}$ & $\begin{array}{l}\text { Jumlah } \\
\text { Teoritis }\end{array}$ \\
\hline 1 & Badan Atas (LED Base ) & 1 & 360 & 360 & & $9-5$ & 4 & $0-1$ & 2,5 & 4 & 2,5 & 1 \\
\hline 2 & Karet Penghubung Badan Bawah & 1 & 180 & 360 & & $2-5$ & 2,57 & $0-2$ & 2,5 & 2,57 & 2,5 & \\
\hline 3 & Plat Badan Bawah & 1 & 360 & 360 & & $3-0$ & 1,95 & $0-1$ & 2,5 & 1,95 & 2,5 & 1 \\
\hline 4 & LED Driver & 1 & 360 & 360 & & $2-0$ & 1,8 & $0-1$ & 2,5 & 1,8 & 2,5 & 1 \\
\hline 5 & Fastener 1 & 2 & 360 & 0 & 2,9 & $1-1$ & 1,8 & $3-9$ & 8 & 3,6 & 16 & \\
\hline 6 & Penutup Bawah & 1 & 360 & 360 & & $3-0$ & 1,95 & $0-1$ & 2,5 & 1,95 & 2,5 & 1 \\
\hline 7 & Fastener 1 & 6 & 360 & 0 & 2,9 & $1-1$ & 1,8 & $3-9$ & 8 & 10,8 & 48 & \\
\hline 8 & Reorientasi & 1 & 360 & 360 & & $9-5$ & 4 & $0-1$ & 2,5 & 4 & 2,5 & \\
\hline 9 & PCB LED & 1 & 360 & 360 & & $3-0$ & 1,95 & $0-1$ & 2,5 & 1,95 & 2,5 & 1 \\
\hline 10 & Fastener 2 & 12 & 360 & 0 & 2,9 & $1-1$ & 1,8 & $3-9$ & 8 & 21,6 & 96 & \\
\hline 11 & Kabel LED Driver & 2 & 360 & 360 & 2,9 & $3-1$ & 2,25 & $9-5$ & 8 & 4,5 & 16 & 2 \\
\hline 12 & Papan Pembias & 1 & 360 & 180 & & $2-0$ & 1,8 & $0-1$ & 2,5 & 1,8 & 2,5 & 1 \\
\hline 13 & Fastener 3 & 14 & 360 & 0 & 2,9 & $1-2$ & 2,25 & $3-9$ & 8 & 31,5 & 112 & \\
\hline 14 & Karet Kaca & 2 & 180 & 180 & & $1-5$ & 2,25 & $4-3$ & 7,5 & 4,5 & 15 & \\
\hline 15 & Reorientasi & 1 & 360 & 360 & & $9-5$ & 4 & $0-1$ & 2,5 & 4 & 2,5 & \\
\hline 16 & Kaca & 1 & 360 & 360 & & $9-3$ & 3 & $4-2$ & 6,5 & 3 & 6,5 & 1 \\
\hline 17 & Karet Penghubung Penutup Atas & 1 & 180 & 360 & & $2-5$ & 2,57 & $0-2$ & 2,5 & 2,57 & 2,5 & \\
\hline 18 & Penutup Atas & 1 & 360 & 360 & & $3-0$ & 1,95 & $0-1$ & 2,5 & 1,95 & 2,5 & \\
\hline 19 & Fastener 1 & 8 & 360 & 0 & 2,9 & $1-1$ & 1,8 & $3-9$ & 8 & 14,4 & 64 & \\
\hline \multicolumn{2}{|c|}{ Jumlah } & 58 & & & 17,4 & & & & & 122,44 & 401 & 9 \\
\hline \multicolumn{2}{|c|}{ Total Waktu Assembly } & 540,84 & & & & & & & & & & \\
\hline \multicolumn{2}{|c|}{ Efisiensi Desain } & $15,52 \%$ & & & & & & & & & & \\
\hline
\end{tabular}

6) Perhitungan estimasi ongkos pembuatan produk dan break event point produk usulan.

Selain melakukan perhitungan waktu perakitan dan efisiensi desain, diperlukan pula perhitungan ongkos pembuatan produk untuk mengetahui estimasi total biaya yang dibutuhkan untuk membuat satu produk. Perhitungan estimasi total biaya pembuatan produk usulan dapat dilihat pada Tabel 7. 
Tabel 7. Estimasi Total Biaya Pembuatan Produk Usulan dan BEP

\begin{tabular}{|c|c|c|c|c|c|}
\hline \multirow{2}{*}{ Biaya Material } & Material Komponen & $\mathrm{Rp}$ & 1.048 .571 & \multirow[b]{3}{*}{$\mathrm{Rp}$} & \multirow[b]{3}{*}{1.104 .171} \\
\hline & Material Fastener & $\mathrm{Rp}$ & 55.600 & & \\
\hline & & & & & \\
\hline \multirow{2}{*}{ Biaya Fabrikasi } & Permesinan & $\mathrm{Rp}$ & 546.062 & & \\
\hline & Operator & $\mathrm{Rp}$ & 42.392 & & \\
\hline & & & & $\mathrm{Rp}$ & 588.453 \\
\hline \multirow{2}{*}{ Biaya Depresiasi } & Mesin & $\mathrm{Rp}$ & 27.448 & & \\
\hline & Cetakan & $\mathrm{Rp}$ & 12.536 & & \\
\hline & & & & $\mathrm{Rp}$ & $39.984,66$ \\
\hline \multicolumn{4}{|c|}{ Estimasi Total Biaya Pembuatan Produk Us ulan } & $\mathbf{R p}$ & 1.732 .609 \\
\hline \multicolumn{2}{|l|}{ Kapasitas } & & 50000 & & \\
\hline \multicolumn{4}{|l|}{ Profit } & $\mathrm{Rp}$ & 38.369 .534 .850 \\
\hline \multicolumn{2}{|l|}{ Harga Produk } & $\mathrm{Rp}$ & $2.500 .000,00$ & & \\
\hline \multicolumn{2}{|l|}{ Investasi } & $\mathrm{Rp}$ & $984.000 .000,00$ & & \\
\hline \multicolumn{4}{|l|}{ Break Event Point } & & 1283 \\
\hline
\end{tabular}

\section{ANALISIS DAN KESIMPULAN}

Analisis serta kesimpulan yang diperoleh dari hasil penelitian adalah:

1. Estimasi total waktu perakitan rancangan usulan dibandingkan dengan rancangan existing mengalami penurunan dari 1150,1 detik menjadi 540,84 detik atau sebesar 53\%. Dengan berkurangnya waktu perakitan ini, ongkos yang dikeluarkan untuk operasi perakitan produk menjadi lebih murah.

2. Estimasi efisiensi desain rancangan usulan dibandingkan dengan rancangan existing mengalami kenaikan dari 7,63\% menjadi $15,52 \%$. Dengan peningkatan efisiensi desain ini, proses perakitan komponen menjadi lebih mudah dan ringan.

3. Jumlah komponen pada rancangan usulan mengalami penurunan dari 118 buah komponen menjadi 58 buah komponen. Dengan lebih sedikitnya komponen yang digunakan, biaya simpan gudang yang dikeluarkan juga secara teoritis dapat mengalami penurunan.

4. Penggunaan fastener pada produk usulan diminimasi variansinya dari 4 jenis menjadi 3 jenis dengan menghilangkan penggunaan baut dan mur. Perubahan ini dapat meminimasi komponen yang dibutuhkan serta dapat mengurangi biaya material produk.

5. Dari perubahan rancangan desain, perusahaan mendapatkan tambahan laba sebesar Rp99.111,- per produk apabila produk usulan dijual dengan harga yang identik dengan harga produk existing.

6. Keuntungan dari mengecilnya angka break event point mengartikan bahwa modal yang dikeluarkan akan lebih cepat terganti apabila menggunakan rancangan desain usulan dan semakin banyak laba yang didapatkan oleh perusahaan.

\section{DAFTAR PUSTAKA}

[1] Adryana, Rangga S. 2014. Perancangan Ulang Prototype Produk Smart Lamp Menggunakan Metode Design For Assembly (DFA). Laporan Kerja Praktik. Program Sarjana Institut Teknologi Bandung, Bandung.

[2] Boothroyd, G., Dewhurst, P., Knight, W.,. 2011. Product Design for Manufacture and Assembly. Edisi 3. Taylor \& Francis Group: CRC Press

[3] Boothroyd, \& Dewhurst. 1994. A decade of DFMA Research. The 1994 International Forum on Design For Manufacture and Assembly. New Port, Rhode Island.

[4] Sutrisno. 2012. Manajemen Keuangan: Teori Konsep \& Aplikasi. Edisi 8. Yogyakarta: Ekonisa 
Arief Irfan Syah Tjaja, Rochmat Puji Astomo, Rispianda

[5] Yusri. 2008. Penerapan Design for Assembly (DFA) untuk Mereduksi Biaya Produksi Suatu Produk. Jurnal Online. Program D3 Politeknik Negeri Padang, Padang. 